\title{
БЛАГОРОДНОМЕТАЛЛЬНАЯ МИНЕРАЛИЗАЦИЯ В КОМАТИИТАХ И ИНТРУЗИВНЫХ УЛЬТРАБАЗИТАХ В АРХЕЙСКИХ ЗЕЛЕНОКАМЕННЫХ ПОЯСАХ КАРЕЛИИ (ОБРАМЛЕНИЕ ВОДЛОЗЕРСКОГО БЛОКА)
}

Кулешевич Л.В.

Институт геологии КарНЦ РАН, Петрозаводск, kuleshev@krc.karelia.ru

Металлогенический потенциал ультраосновных комплексов архейских зеленокаменных поясов (ЗП), обрамляющих Водлозерский блок и формировавшихся 3.0-2.85 млрд. лет назад в обстановках задуговых бассейнов, определяется медно-никелевыми рудами, в меньшей мере хромитовыми, и ассоциирующими с ними элементами платиновой группы (PGE). Пентландитхалькопирит-пирротиновые руды установлены в коматиитах и интрузивных ультрабазитах. Вкрапленно-прожилковые и вкрапленно-пластовые залежи тяготеют к нижним («придонным») частям интрузивов или крупных коматиитовых тел, расположенных вблизи колчеданных залежей. К богатым прожилковым и брекчиевидным рудам, содержащим халькопирит, тяготеют повышенные концентрации платиноидов. Рудные тела представлены несколькими генерациями сульфидов, сформированных на разных стадиях процесса рудообразования и преобразования вещества. На коллизионном этапе вмещающие и интрузивные комплексы ЗП деформируются, их преобразования отвечают преимущественно зеленосланцевой - эпидот-амфиболитовой фациям метаморфизма, в локальных сдвиговых зонах породы бывают сильно рассланцованы и подвергаются метаморфогенно-метасоматическим изменениям. Ультрабазиты замещаются серпентинитами, тальк-хлорит-(тремолит)-серпентиновыми, тальк-карбонат-хлоритовыми и тальковыми сланцами, иногда лиственитами. При этом возникают месторождения нерудного сырья - серпентинитов, тальк-хлоритового камня и талька. На этом этапе происходит замещение хромита на магнетит, пентландита и пирротина на миллерит, пирит, в ассоциации с ними, тем не менее, встречаются сульфоарсениды и стибиоарсениды PGE. Вынос Ni и Cr во вмещающие толщи сопровождается их частичным рассеянием и образованием $\mathrm{Ni}-\mathrm{Co}-\mathrm{Sb}$-S-As-минерализации (кобальтина, герсдорфита и др.) и фукситовых сланцев. Ni-Co-стибиосульфоарсениды входят уже в Au-S-As aссоциацию позднеархейских шир-зон.

Целью проводимой работы было изучение благородных металлов в медно-никелевых рудах архейских ультрабазитов Карелии и создание базы данных полезных ископаемых (Ni, Cr, Pt) конкретных литогеодинамических обстановок. В задачи входило установление распределения $\mathrm{Ni}, \mathrm{Cu}$, $\mathrm{Co}, \mathrm{Cr}$ и платиноидов (PGE и минералов) в архейских рудопроявлениях в обрамлении Водлозерского блока. Содержание элементов в породах и рудах определялось с помощью ICP-MS анализа, минералы никелевых, хромитовых руд и платиноиды в них изучались с использованием микрозондового анализатора в ИГ КарНЦ РАН (г. Петрозаводск). Для наполнения базы данных использовались авторские материалы по изучению платиноидов, результаты опробования ультрабазитов отдельных структур и данные минерально-сырьевой базы Р. Карелия [5].

В разновозрастных ЗП Канады выделяются два уровня ультраосновного магматизма мезо- и неоархейского возраста. Причем более значительные ресурсы никелевых руд сосредоточены в неоархейских ЗП, в ультрабазитах, контаминированных серой. Как показано в анализе С.А. Турченко [8], в более древних (>3 млрд. лет) ультрабазитах ЗП Земли крупные месторождения никеля не встречаются, в отличие от неоархейских ЗП, содержащих крупные месторождения. Для архейских ЗП Карелии характерны несколько возрастных интервалов проявления ультрабазитового магматизма и различная контаминация серой. В мезоархейских ЗП в обрамлении Водлозерского блока ультрабазиты встречаются на двух возрастных уровнях. Более контаминированы серой коматииты и ультрабазиты, совмещенные с колчеданными залежами, в них и были выявлены все основные сульфидные медно-никелевые рудные объекты, такие как небольшие месторождения и проявления Каменноозерской, Хаутаваарской структуры. (В Костомукшской структуре такие проявления отсутствуют). Рассмотрим месторождения /рудопроявления $\mathrm{Ni}, \mathrm{Cr}$ и присутствие в них платиноидов по отдельным площадям и рудным объектам в ультрабазитах в ЗП обрамления Водлозерского блока. 
Ведлозерско-Сегозерский ЗП В Ведлозерско-Сегозерском ЗП на Хаутаваарской площади ультраосновные породы выявлены на двух возрастных уровнях и представлены коматиитами и интрузивными ультрабазитами. Более древние ультраосновные породы (3.05-2.94 млрд. л) развиты в лоухиваарской свите, более молодые ( 2.9-2.85 млрд. лет) - секут калаярвинскую свиту. Коматииты и интрузивные ультрабазиты образуют пластовые тела разной длины и мощности. Наиболее крупные дифференцированные интрузии ультрабазитов Хюрсюля (длиной 10 км), Кивач (7 км), Петусъярви (10 км) представлены оливинитами, перидотитами и прорывющими их пироксенитами, габбро, габброноритами (возраст последних 2.83 млрд. л.). В восточной части Хаутаваарской структуры ультрабазиты пересекают колчеданные руды, где и были установлены наиболее высокие концентрации $\mathrm{Ni}$ и Pt-Pd. К наиболее значимым проявлениям никеля относятся Хаутаваарское-Ni, Хюрсюльское, Суриярвинское, Кайноважа. Средние содержания $\mathrm{Ni}$ на этих рудных объектах составляют 0.26-0.6 \%. Хаутаваарское никелевое месторождение было выявлено благодаря детальным производственным работам, проводимым КГЭ (Мустонен, 1954 г., Бреслер, 1955 г.; С.А. Морозова, 1973 г.). Руды вкрапленно-прожилковые, халькопирит-пентландит-пирротиновые по сотставу. Ресурсы никеля составляют около 3 тыс. т, при среднем содержании 0.49 \% Ni (максимально - до 1.5 \%). В рудах с содержанием $\mathrm{Cu}$ до 1 \% установлены платиноиды: $\sum \mathrm{PGE}$ - от 1-4.3 г/т (по данным М.М. Лаврова, Н.Н. Трофимова) до 8 г/т (по, данным В.В. Сиваева за 1988 г.). В слабоминерализованных ультрабазитах и сланцах по ним $\sum$ PGE не превышает 0.045-0.007 г/т, в рудах C-154 - 0.8-1.1 г/т, C-152 - 2.85 г/т. Платиноиды педставлены меренскитом, Pd-мелонитом, сперрилитом, Pd-Ni-Bi-Sb-Te-фазами, встречаются теллуросадбериит, холингвортит [3]. Метаморфогенно-метасоматические преобразования сопровождаются образованием хлорит-тальк-карбонат-тремолитовых сланцев и переотложением платиноидов совместно с $\mathrm{Cr}$ во вмещающие сланцы, в которых содержание $\sum$ PGE достигает 3.18-4.3 г/т (в фукситовых сланцах) и до 1.71-1.85 г/т (в черных сланцах), Au 0.007-0.12 г/т [4].

В интрузивных ультрабазитах массива Хюрсюля, в двух линзовидных залежах пенландитпирротиновых руд (Ni 0.25-0.5 \%), а также выявлено гипергенное $\mathrm{Ni}-\mathrm{Si}$-проявление. $\sum \mathrm{PGE}$ в рудах достигает 4-8.25 г/т (Au 0.05-0.18 г/т), повышенное содержание PGE отмечается и в пироксенитах. В массиве Кивач содержание $\mathrm{Ni}$ - 0.6-2 \% (в С-5), Cu - 0.6-1.3 \% (по данным С.М. Бреслер, 1956 г.). Повышенные концентрации благородных металлов тяготеют к Ni-pудам ( $\sum$ PGE 0.56 г/т, Au 0.1 г/т). В массиве Петусъярви Ni 0.36-0.43 \%, PGE не превышают предела обнаружения. На участках Ведлозерском и Новые Пески были выявлены лишь маломощные тела ультрабазитов с повышенными концентрациями $\mathrm{Ni} 0.14 \%, \mathrm{Cu} 0.12 \%, \mathrm{Cr} 0.3 \%$, Co 232 ppm в них и в колчеданных рудах.

В Койкарской структуре интрузивные ультрабазиты прорывают центральную часть структуры (северо-западнее колчеданной залежи). Значимых концентраций сульфидов в этих ультрабазитах не обнаружено. Прослои метакоматиитов и их туфов в СВ части структуры образуют маломощные горизонты севернее колчеданной залежи. В них выявлена рассеянная Au-содержащая Ni-S-As минерализация. Комплекс нерасчлененных ультрабазитов Эльмусской площади расположен севернее оз. Педролампи. С ним связаны небольшие никелевые проявления Педроярви и Столбовая гора.

В С3 обрамлении Водлозерского блока (юго-восточнее оз. Сегозеро) известны лишь реликты зеленокаменных структур (3С), сохранившиеся в гранитогнейах. К ним относятся Паламбинская структура, участки Каллиево, Вожемское, Калаламби, Карельская Масельга, Листья губа и др. На этапе метаморфогенно-метасоматического преобразования ультрабазиты этих небольших структур превращаются в хлорит-тальк-серпентиновые, хлорит-тальковые сланцы и талькиты, которые в настоящее время выделяются только как объекты нерудного талькового сырья. При таких изменениях происходит интенсивный вынос рудогенных элементов $(\mathrm{Ni}, \mathrm{Co}, \mathrm{Cr})$ из ультрабазитов. Тем не менее, в сланцах встречается виоларит-пирротиновая или миллерит-пиритовая минерализация с $\mathrm{Ni-cульфоарсенидами} \mathrm{и} \mathrm{платиноидами} \mathrm{(сульфоарсениды} \mathrm{палладия,} \mathrm{садбериит,} \mathrm{сперрилит).}$

В Сумозерско-Кенозерском ЗП коматииты и интрузивные ультрабазиты наиболее широко представлены в Каменноозерской зеленокаменной структуре. Платинометалльная минерализация установлена в никелевых и хромитовых рудах, связанных с коматиитами и интрузивными ультрабазитами, которые здесь также встречаются на двух возрастных уровнях. В коматиитах Кумбуксин- 
ской зоны на участках Золотые Пороги и Лещевском выявлены несколько пластовых тел коматиитов, в которых установлены залежи вкрапленно-прожилковых халькопирит-пентландит-пирротиновых и миллерит-(магнетит)-пиритовых руд с содержанием Ni 0.52-0.87 \% (до 3.5 \%), Cu 0.02-0.2\%, Со 0.01-0.1 \% (по работам В.Н. Фурмана и В.М. Тытыка за 1983-1997 годы. В халькопиритпентладит-пирротиновых рудах участка Лещевского содержание $\mathrm{Ni}$ составляет 0.37-1.8 \%, $\mathrm{Cu}$ 0.02-0.15 \%, Сo 0.011-0.062 \%. Запасы никеля Золотопорожского проявления по категории $\mathrm{C}_{1}+\mathrm{C}_{2}$ составляют 6.2 тыс. т, ресурсы - 9.3 тыс. т. В этих рудах обнаружена рассеянная платинометалльная минерализация (сперрилит, арсенопалладинит).

Однако основной металлогенический потенциал Каменноозерского рудного района составляют $\mathrm{Cu}-\mathrm{Ni}$-месторождения и проявления, связанные с интрузиями ультрабазитов Каменноозерского комплекса. Среди них наиболее значительны месторождения Восточно-Вожминское, проявления Вожминской группы (Центрально- и Западно-Вожминские залежи № 1-5), Кумбуксинское, Лебяжинское, Светлоозерское (Центральное и Восточное). Содержание сульфидов в рудах колеблется от 5-10 до 80-100 \%. Средние содержания Ni на месторождениях Каменноозерской группы равны 0.3-1.03\%, максимальные достигают некольких \% (на Восточно-Вожминском месторождении 3-4 \%, на Лебяжинском - 0.41-8 \%). Запасы категорий $\mathrm{C}_{1}$ и $\mathrm{C}_{2}$ в разных объектах составляют 20.2-33.9 тыс. т, а прогнозные ресурсы оцениваются от 15.8 до 66.2 тыс. т, по данным производственных работ КГЭ (В.М. Тытыка, А.В. Федюка, В.Н. Фурмана, С.А. Морозова, [5]). Эти же проявления оценивались и на медь, запасы которой составляют 1.6-13.9 тыс. т, ресурсы от 2 до 78 тыс. т (по разным объектам) при средних содержаниях $\mathrm{Cu}$ 0.1-0.42 \% (до 3.2 \%), Со 0.02-0.17 \%. К рудам богатым медью приурочены наиболее значимые концентрации платиноидов: среднее содержание $\sum \mathrm{PGE}=1$ г/т (Pt до 1.07, Pd - 3.5 г/т). На Восточно-Вожминском месторождении установлены $\mathrm{Pd}-$ мелонит, сперрилит, стибио-теллуро-палладиниты. В халькопирит-пентландит-пирротиновых вкрапленно- прожилковых рудах (C-109) проявления Светлое распространены кобальтин, сперрилит, стибиопалладинит, мертиит, встречается ирарсит, золото, галенит, а в ассоциации с миллеритом и пиритом (С-144) обнаружены стибиопалладинит, золото.

Хромитовые руды в Каменноозерской структуре были обнаружены лишь в нескольких интрузиях. Залежи маломощные с невысокими средними концентрациями Cr, Ni и PGE. На рудопроявлении Лексинском содержание $\mathrm{Cr}_{2} \mathrm{O}_{3}$ достигает 33 \%, Прибрежном - 29.6 \%, Приграничном - 23.3 \% [5]. На Лексинском проявлении в хромитовых рудах обнаружены высокотемпературные платиноиды, лаурит, сперрилит.

В Южжно-Выгозерском ЗП коматииты и интрузивные ультрабазиты представлены в небольших архейских 3С - Рыбозерской и Конжозерской. Зеленокаменные породы прорываются Шилосско-Рыбозерским плагиогранитным массивом, возраст которого 2.86 млрд. л. С коматиитами связаны Cu-Ni-S руды проявлений Рыбозерское, Западно-Рыбозерское, группа Конжозерских (№ 1, Южным, Северным), Ялдозерское, Ламбозерское. В никелевых рудопроявлениях участка Рыбозеро средние содержания $\mathrm{Ni}$ составляют 0.34-0.54 \%, в группе Конжозерских - 0.38 (до 1.63 \%), на участке Ламбозерском - до 0.65 \% [5]. Рудопроявления Западного фланга Рыбозерской структуры приурочены к амфиболитам по пироксенитам и вмещающим толщам. В комплексных V-Ti-Fe$\mathrm{S}-\mathrm{Cu}-\mathrm{Ni}$-рудах (C-7) кроме Ti-Fe-оксидов ( $\mathrm{Fe}_{\text {ср. }} 17.3$ \%) развиты сульфиды - халькопирит, пирротин, пирит, пентландит, виоларит (по пентландиту), мелонит NiTe, сфалерит, реже встречаются рениит, селеногаленит, гринокит. В ассоциации с пентландитом, замещенным виоларитом, обнаружены $\mathrm{Ni-меренскиит,} \mathrm{Sb-майченерит,} \mathrm{Pd-мелонит,} \mathrm{сперрилит} \mathrm{[2].} \mathrm{¿PGE} \mathrm{в} \mathrm{скважинах} \mathrm{западной} \mathrm{плолосы} \mathrm{в}$ хлорит-тальк-тремолитовых сланцах составляет 0.13-1.29 г/т [7]. В зонах вкрапленно-прожилковой переотложенной во вмещающие толщи (C-1-3) Cu-Ni-сульфидной минерализации установлены пирит, пирротин, пентландит и виоларит (в сумме 10-30 \%), Au - до 2.1 г/т. На стадии метаморфогеннометасоматических преобразований коматииты восточной ветви участка полностью преобразованы в хлорит-карбонат-тальковые сланцы и листвениты. Ni и Со в процессе лиственитизации интенсивно мигрировали и переотлагались в новообразованных ассоциациях руд, содержащих золото: в фазах глаукодот-кобальтин-герсдорфит, ульманнит-вольфахит, мелонит-Pd-мелонит $[1,2]$. 
Хромитовые руды приурочены к интрузивному телу в южной части Рыбозерской структуры, где установлено рудопрявление Ладвозерское (Рыбозерское $\mathrm{Cr}$ ). Среднее содержание $\mathrm{Cr}_{2} \mathrm{O}_{3}$ в нем составляет в $16 \%$ (до $32.2 \%$ ), ресурсы оцениваются в 13 млн. т (по данным С.Н. Юдина за 1991 г.). Ультрабазиты и хромитовые руды скважины С-9 содержат повышенные концентрации Ni 0.1-0.3 \%, Co 100-386 ppm, Cu 260, $\sum \mathrm{PGE}=0.1-0.31$, Au 0.15-0.19 ppm. В хромитовых рудах, кроме хромшпинелидов и магнетита, встречаются пентландит, никелин, в оталькованных породах - более поздние Ni-Со-сульфиды (миллерит, полидимит). Установлены и более высокотемпературные платиноиды, такие как лаурит (Ru 48.39-48.91 \%, Rh 2.56-2/1 \%, Os 7.33-7.43 \%, Ir 5.41-5.53 \%, S 36-36.3 \%), ирарсит, холлингвортит, сперрилит, мончеит, платина, стибиопалладинит [3].

Маткалахтинский ЗП заложился по зоне ССВ раскола в центральной части Водлозерского блока среди гранитогнейсов. В его строении установлены мощные покровы коматиитов, среди которых обнаружена лишь одна маломощная прожилковая зона с содержанием $\mathrm{Ni} 2.41$ \%, Cu 0.11, Со 0.18 \% (проявление Верхний Рогой, [5]).

Из приведенного обзора видно, что небольшие $\mathrm{Cu}$-Ni-рудные объекты Карелии по своим ресурсам значительно уступают докембрийским месторождениям Австралии и Канады [6]. Однако в общем анализе эволюции процессов мантийного рудообразования в раннем докембрии Карелии они представляют несомненный интерес и, в целом, вносят вклад в общий металлогенический потенциал региона. Работа выполняется в рамках тем НИР ИГ КарНЦ РАН (2018-2022).

\section{Литература}

1. Кулешевич Л.В. Золотоносность Южно-Выгозерского зеленокаменного пояса (Восточная Карелия) // Отечественная геология. 2005. № 2. С. 38-46.

2. Кулешевич Л.В. Золоторудное месторождение Рыбозеро в Южно-Выгозерском зеленокаменном поясе (Восточная Карелия) // Геология и полезные ископаемые Карелии. № 16. Петрозаводск. 2013. С. 89-101.

3. Кулешевич Л.В. Платиноиды в сульфидно-медно-никелевых и хромитовых рудах ультрабазитов архейских зеленокаменных поясов Карелии // «Петрография магматических и метаморфических горных пород». Петрозаводск. 2015. С. 438-441.

4. Кулешевич Л.В., Слюсарев В.Д., Лавров М.М. Благороднометалльная минерализация ХаутаваароВедлозерской площади // Геология и полезные ископаемые Карелии. № 12. 2009. С. 12-25.

5. Минерально-сырьевая база Р. Карелия // Михайлов В.П. и др. Кн. 1. 2005. 278 с.

6. Петров О.В., Гурская Л.И., Феоктистов В.П. Металлогения никеля и перспективы развития его сырьевой базы в России // Региональная геология и металлогения. № 54. 2013. С. 64-74.

7. Слюсарев В.Д., Голубев А.И. Элементы платиновой группы в породах Южно-Выгозерского зеленокаменного пояса // Геология и полезные ископаемые Карелии. № 6. Петрозаводск. 2003. С. 12-25

8. Турченко С.И. Особенности формирования сульфидно-никелевых и платиноносных (Ni-MПГ) руд в архейских провинциях // Региональная геология и металлогения. № 66. 2012. С. 91-94. 